\title{
Repertoire Selection Processes of Basic School Marching Band Instructors in Ghana
}

\author{
John-Doe Dordzro
}

\section{ABSTRACT}

\begin{abstract}
The purpose of this study was to investigate into the repertoire selection practices of Basic school marching band instructors in Ghana. Questionnaire and semi-structured interview guide designed for the collection of data obtained demographic information and identified the criteria and procedures used by basic school band directors in selecting repertoire for their bands. An instrumental case study design allowed me to gain an in-depth understanding of band instructors' perspectives. Data were solicited from 26 school band directors selected using snowball sampling method. Of the 26 directors invited to participate, all agreed to do so and actually responded to all questions. Results revealed that the three most frequently reported sources of repertoire selection were other band experiences, recommendations from colleagues, and school ensemble participation. The three factors most frequently reported as affecting repertoire selection decisions were the appeal of the music to self, appeal of the music to colleagues, the audience appeal to the music, and students' appeal to music. Recommendations drawn from the research findings included the following: repertoire for school band methods and wind literature classes needs to be more adequately addressed, and school band instructors in Ghana should focus more on 'quality' and consider the human subjective elements as alternatives.
\end{abstract}

Keywords: instrumental music, music education programming repertoire selection, school marching band

\section{INTRODUCTION}

The basic school band is arguably the most important phase when it comes to instructional sequencing and the development of wind and percussion instrumentalists. In the Ghanaian educational structure, the basic school corresponds generally to the ages often through six to fourteen years. It is important that more attention is given to what actually goes on in band classrooms, since it is at this level of musical development that playing habits are taught, learned and refined. Without proper instruction at this level, further development of musicianship and technical ability may be severely affected. The basic school years provide some unique teaching and learning opportunities, yet, at the same time, the Ghanaian instrumental music teacher is continually challenged to find interesting and appropriate music literature for these young developing instrumentalists.

Over the past decades, school instrumental music education has tended to be performance-oriented, thereby, making repertoire selection to support ones instruction inevitable [1]. While most of the available repertoire recommended for this level is not necessarily "art" music, the kinds of music that are selected usually serves rather in a pedagogical role. Ensemble repertoire functions as a medium through which musical concepts and other aspects of musical curriculum, music
Published Online: December 13,2020

ISSN: $2736-4534$

DOI: $10.24018 / 2020.1 .1 .7$

John-Doe Dordzro *

University of Cape Coast, Ghana

(e-mail: doe.dordzro@ucc.edu.gh)

*Corresponding Author study (theory, history, composition, and various musical genres) are taught and reinforced to foster students' growth and development as musicians [2]-[5]. That is why Apfelstadt [6] states that the repertoire selected as part of the curriculum of a school ensemble is one of the most important decisions made each school year. Up till now, the challenge to basic school band instructors, especially in Ghana, lies: in the availability of quality instrumental works for school bands, and choosing age-specific repertoire that is neither boring nor too difficult for instrumentalists to get them easily frustrated.

The most frequently cited criterion for the selection of repertoire is the inclusion of music of different historical periods. Several authors have stressed the importance of a wide-ranging repertoire because it provides for diverse educational experiences [3], [5], [7], [8]. The issue of culturally diverse music cannot be ignored when making repertoire selection decisions. Numerous authors indicated the importance of including repertoire reflective of world cultures [5], [7], [9], [10].

Researchers have also agreed that the parameters of the performing ensemble should be considered when selecting repertoire for performance. These parameters include the following: the size of the ensemble; the technical ability of the ensemble; the musical and physical maturity of the 
performers; and the musical tastes, preferences, and interests of the ensemble [5], [11], [12]. However, O'Reilly and Williams [13] advised that dividing first-year players into first and second players may destroy the confidence of half the group. Since most first-year and second-year bands found in the typical basic school setting might not contain all of the instrumental forces, particularly the 'colour' instruments, repertoire selection becomes a sensitive issue for the director. Therefore, literature must be selected that fits both the size of the ensemble as well as the instruments available within the ensemble. To resolve such issues, Gage [14] advocates occasional re-scoring to cover missing lines or parts, but advises that it is probably not wise to programme pieces, too often, which are specifically scored for voices that are not present.

More so, three areas relative to the director must be considered when selecting repertoire. Authorities have identified director interest, ability, and education as areas crucial to the repertoire selection process [11]. According to Mayhall [15], in-depth score study, enthusiasm for rehearsal, and sustained interest are difficult to accomplish for the director unless a powerful attraction is present in the music. Gregory [16] advised that directors must maintain interest in all aspects of their job functions, perhaps including the tasks associated with repertoire selection, in order to avoid what he terms "burnout" (p. 32). Labuta [17] writes that "band directors are slow to accept curricular changes" and that "band directors will not implement change until easy-to-use materials are available and practical for use" (p. 6).

Perhaps the most important consideration associated with the task of repertoire selection deals with the music itself. Criteria related to the music will necessarily include such factors as the quality, the level of technical difficulty, artistic demands upon the performers, the performing resources required, the intricacy of the individual parts, and the overall aesthetic effect of a given composition. Scholars demonstrated historical consistency in arguing that repertoire selected for performance must be of high quality [6]-[8], [18], [19]. While individual recommendations may differ among authors, the presence of elements that affirm the level of quality of the music is virtually mandatory. Leonhard and House [20] define high quality or "good" music as "that which possesses craftsmanship and expressivity” (p. 102). Apfelstadt [6] expands upon this assessment, stating that "well-written music finds the balance of tension and release, structural symmetry and asymmetry, and anticipation and surprise that makes listening and performing it a worthwhile experience" (p. 19). Roseboom [21] explains that all good music are expressive in form and content, something of depth, which embodies the composer's conception of the stress-release form of the human experience, and craftsmanship can be defined as the element that facilitates expressiveness.

Quality in music, and the musical elements that elevate a work to a level of high quality, are considerations that have long been debated. Miller [12] and Weller [5] notes four criteria for assessing the quality of art work developed by Reimer [22]: craftsmanship, sensitivity, imagination, and authenticity (pp. 135-137). Reimer conceptualized craftsmanship as the expertness by which the materials of art are moulded into expressiveness and opined that works lacking craftsmanship are signaled by shoddiness, by disrespect for materials, by the skill that manipulates the material rather than serving its expressiveness. Reimer discusses the other three criteria (sensitivity, imagination, and authenticity) at length.

But what of the younger ensembles, the elementary and beginning and intermediate level bands, such as those found in the basic schools? What body of quality repertoire exists for those less experienced ensembles? Hoffer [7] suggests that music for younger students be selected in part according to such factors as repetition (reducing the amount of time needed to learn the music), length (the longer the work, the more time needed to learn it), rhythm (because adolescents are attracted to music that has rhythmic interests), and musicianship of the students (noting that there is a limit to which adolescents can be pushed in subtleties or symbolism). Authorities generally agree that the technical difficulty of a given work should be considered when selecting repertoire for study and performance. Technical difficulty appears to be a relative phenomenon, as more demanding works are generally intended for ensembles of more advanced ability. In other words, a grade four work would not under most circumstances be programmed for an ensemble of grade six students (although granted, there are probably a few exceptions to this dictum.) There are several elements of the music that should be considered when selecting repertoire; range and tessitura of the individual parts; melodic, harmonic, and rhythmic complexity; duration, key; runs (scale wise or otherwise); instruments on a particular part; length of difficult passages; and overall musical arrangement [2], [3], [7], [14], [19], [23]-[25].

The study of school ensemble rehearsal has gathered momentum over the past decades as instrumental music education researchers have begun to uncover the complex skills involved in developing musical expertise and preparing a performance. Such studies (e.g [5], [12], [25]) have raised vital issues about instructional practice, including questions on repertoire selection, the quantity of rehearsal and quality of performance. Unfortunately, that cannot be said about the situation in Ghana in particular. Little research exists on school bands and their practices (see [28], [29]). Thus, the primary purpose of this study is to investigate the means through which basic school marching band instructors select repertoire in Ghana. As evident in the above discussion, studies on repertoire selection is historically not a new idea, however, there is limited empirical research on repertoire selection for school instrumental ensembles in Ghana.

The current study has the potential of opening up discussions as to; what specific works should appear on such a list, and the criteria used in selecting the pieces. The need for this study becomes stronger considering the fact that, in other parts of the world, like the United States of America, the selection process is narrowed down where they have textbook series provided by the school districts, or in performance-based ensembles, where the state contest list can determine at least some of the repertoire choices relating to the National Standards and/or there are also professional bodies, such as The National Band Association, who has it as one of its core mandate to publish lists of repertoire appropriate for the bands at the various educational levels. What is the situation in Ghana? Is there a list of repertoire for 
every level? Are the teachers left to take this important decision on their own? Who decides the quality of pieces selected as repertoire for school bands? These are pertinent questions that served as the foundation for the current study.

\section{METHOD}

An instrumental case study design (Stake, 2005 as cited in Forrester [26]) allowed me to gain an in-depth description of the processes through which basic school marching band instructors select repertoire for their instrumental ensembles. Stake described the purpose of an instrumental case study "...to provide insight into an issue or to redraw a generalization. The case is of secondary interest, it plays a supportive role, and it facilitates our understanding of something else" (p. 437). Furthermore, case study approach can be used in a research that facilitates exploration of a phenomenon within its context using a variety of data sources [27]. In the current study, the case was bound by the phenomena: basic school band instructors' processes and knowledge with regard to repertoire selection, in the context of school instrumental music programme.

In the early stages of this study, it became readily apparent that there was little literature on the topic of repertoire selection for school bands in Ghana. It was even more evident, through the study and examination of repertoire lists from state and national organizations that the vast majority of such lists tended to focus on high school and college-level bands in Asia, Europe and America. Therefore, initial contacts consisted of telephone, and in-person interviews with three expert band directors. The three expert band directors were interviewed separately and later put together in a virtual focus group discussion (virtual meeting via zoom) to determine the types of questions necessary for the questionnaire. This decision was based on the fact that there is scant literature available on this topic in Ghana.

The initial emphasis was to determine interest and the need, if any, for this study. It became readily apparent from the responses from the three experts that considerable interest was indicated in the topic. Based on the interviews with the experts and the available literature, several areas were identified that warranted exploration. These areas included repertoire selection practices, specific repertoire selected, factors that influenced the selection of specific repertoire, and the sources utilized by the directors to select repertoire. The early findings associated with repertoire selection, particularly how directors selected and programmed specific repertoire, were highly consistent with the outcome of the study. Therefore, three questions guided the current study: What styles and types of repertoire do school band instructors select for their bands? What methods and resources do band instructors use to select repertoire? What factors influence the repertoire selection decisions of band instructors?

Two main instruments were used for data collection: interview and questionnaire. Observation was employed in this study mainly for the purpose of verification: to have a firsthand insight into the kind of pieces school bands perform and to examine whether the directors' self-reports via the questionnaire and interviews were supported by my observations. The questionnaire used in this study utilized both open- and closed-ended questions. The first part solicited demographic information on the school, the band programme, and the director. The second part requested information using Likert scale responses, about the sources of repertoire selection employed by the director, as well as the factors affecting repertoire selection. The final part was the interview. The use of the semi-structured interview allowed for follow-up interviews (in person and by telephone) for probing and also to help verify my interpretation and conclusions. A pilot study was conducted to evaluate the strength and weaknesses of the questionnaire before it was administered. The interview guide was also tested to examine the trustworthiness, exploring subjectivity, reflexivity, and the social interaction of interviewing.

Data collection for the current study took place from January to October 2017. Twenty-six school band instructors from the Accra metropolis were identified using the snowball sampling technique (this sampling method was selected since there was no record of school bands available). Descriptive data was collected to: identify the styles and types of repertoire selected by school band instructors, determine what methods and resources were used by these directors to select repertoire, and to determine what, if any, factors influenced the repertoire selection decisions of these directors,

\section{RESULTS}

Demographic information collected concern such factors as years of teaching experience, the instrument played, and gender. The band directors included in this study revealed the categories of band instructors who are currently in charge of Ghanaian basic school bands. The categories included: (a) instructors with postgraduate degrees, (b) instructors with first degrees, (c) instructors with diploma degrees, (d) instructors who are general music teachers but do not play any wind instrument, and (e) instructors who are appointed because of their experience (e.g. retired military or police bandsmen) [28].

Results revealed that all the school band instructors in the Accra metropolis were males (see Fig. 1 below) with ages ranging from 30-50 and above. Levels of teaching experience among band instructors varied from 4 years to more than 20 years.

Some instructors played the clarinet, some played the trumpet, others played the trombone, while a few are general music teachers who played no wind or percussion instruments (see Table 1 below).

Information on band director's educational background revealed most directors reported holding a degree or higher in music. This information is shown in Table 2 below. 


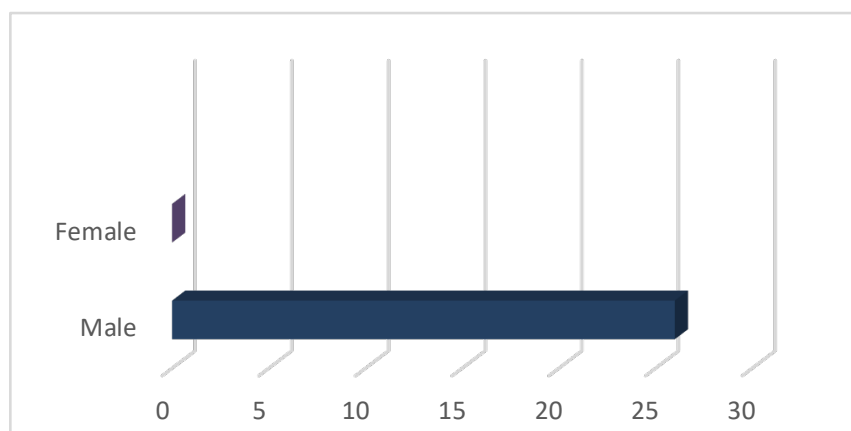

Fig. 1. Gender of school band instructors.

TABLE 1: PRINCIPAL INSTRUMENTS OF INSTRUCTORS

\begin{tabular}{cc}
\hline Musical Instrument & Frequency \\
\hline Trumpet & 14 \\
Trombone & 3 \\
Clarinet & 3 \\
General music teacher & 6 \\
\hline
\end{tabular}

TABLE 2: EDUCATIONAL LEVEL OF SCHOOL BAND INSTRUCTORS

\begin{tabular}{cc}
\hline Degree & Frequency \\
Masters & 2 \\
Degree & 16 \\
Diploma & 2 \\
Certificate & 2 \\
Appointed based on experience & 4 \\
\hline
\end{tabular}

The survey instrument collected information on the source's directors used to select repertoire for their performing ensembles. For each source of repertoire listed on the questionnaire, directors were asked to indicate how often each source was used according to a Likert scale of five responses: $1=$ Never, $2=$ Seldom, $3=$ Sometimes, $4=$ Often, or $5=$ Very Often. Music performed in other groups were reported as being used most often as a tool for selecting repertoire. Other leading sources of repertoire selection included, music you performed in high school, recommendations by colleagues and friends (sample scores, complimentary scores, and recordings), music you performed in College, music you performed in basic school and band festivals. Music publisher materials and state music association lists of repertoire ranked least in the order of sources used by directors. Table 3 shows the responses for the survey population regarding the repertoire sources.

\begin{tabular}{lc}
\multicolumn{2}{c}{ TABLE 3: SOURCES DIRECTORS USED TO SELECT REPERTOIRE } \\
\hline \multicolumn{1}{c}{ Sources } & Mean response $(\mathrm{n}=26)$ \\
\hline $\begin{array}{l}\text { Music you performed in other groups } \\
\text { (church, community bands etc) }\end{array}$ & 3.56 \\
Music you performed in high school & 3.34 \\
Music recommended by colleagues & 3.24 \\
Music you performed in college & 2.98 \\
Music you performed in basic school & 2.95 \\
Band festivals & 2.45 \\
Live performances of other bands & 1.68 \\
Music publisher materials (scores, & 0.65 \\
recordings) & \\
Band workshops(clinics) & 0.45 \\
Readings by your own band & 0.23 \\
Music publisher/distributor & 0.23 \\
catalogues & \\
Examination of scores in music stores & 0.23 \\
Lists of any type form your state & 0.22 \\
music association & \\
Lists published in journals or & 0.14 \\
periodicals & \\
Lists of any type from other state & 0.12 \\
music associations & \\
Any other published repertoire lists & 0.02 \\
\hline
\end{tabular}

The survey also collected information regarding the factors affecting repertoire selection among the directors. For each factor affecting repertoire selection listed on the questionnaire, directors were asked to indicate the level of influence of each factor according to a Likert scale of five responses: 1=Not Considered At All; $2=$ Not An Influence; $3=$ Slight Influence; 4=Moderate Influence; and 5=High Influence.

TABLE 4: IMPORTANCE OF FACTORS AFFECTING REPERTOIRE CHOICE

\begin{tabular}{|c|c|}
\hline Factor & $\begin{array}{l}\text { Mean response } \\
(\mathrm{n}=26)\end{array}$ \\
\hline $\begin{array}{l}\text { Appeal of the music to colleagues (Other band } \\
\text { directors will enjoy hearing this music) }\end{array}$ & 3.10 \\
\hline $\begin{array}{l}\text { Appeal of the music to yourself ("I will enjoy } \\
\text { spending class time to prepare this music") }\end{array}$ & 2.96 \\
\hline $\begin{array}{l}\text { The student appeal of the music ("The students } \\
\text { will enjoy performing this music") }\end{array}$ & 2.91 \\
\hline $\begin{array}{l}\text { The audience appeal of the music ("The audience } \\
\text { will enjoy hearing this music") }\end{array}$ & 2.86 \\
\hline $\begin{array}{l}\text { Rhythmic considerations within the music } \\
\text { (rhythms, patterns, ostinati, etc.) }\end{array}$ & 2.66 \\
\hline $\begin{array}{l}\text { The potential of the music as heard by school } \\
\text { administrators }\end{array}$ & 2.54 \\
\hline $\begin{array}{l}\text { You recently heard another band perform this } \\
\text { music }\end{array}$ & 2.31 \\
\hline $\begin{array}{l}\text { Music to fit the programme ("These two or three } \\
\text { selections create a cohesive and contrasting } \\
\text { programme) }\end{array}$ & 1.66 \\
\hline $\begin{array}{l}\text { Instrumental performance skills that can be taught } \\
\text { through the music (phrasing, balance, tone } \\
\text { quality, intonation, articulation, etc.) }\end{array}$ & 1.12 \\
\hline $\begin{array}{l}\text { Melodic considerations within the music (melodic } \\
\text { line, phrasing, countermelody, harmonic } \\
\text { considerations, etc.) }\end{array}$ & 0.34 \\
\hline $\begin{array}{l}\text { Musical elements that can be taught through the } \\
\text { music (style, form, compositional techniques, } \\
\text { etc.) }\end{array}$ & 0.33 \\
\hline $\begin{array}{l}\text { Social elements of the music (multicultural, social } \\
\text { influences of the time, relation of history to } \\
\text { society) }\end{array}$ & 0.32 \\
\hline $\begin{array}{l}\text { The ability and limitations of the ensemble that } \\
\text { performs this music }\end{array}$ & 0.28 \\
\hline The size of the ensemble that performs this music & 0.26 \\
\hline $\begin{array}{l}\text { The music is of high craftsmanship ("Thus music } \\
\text { has with stood the test of time") }\end{array}$ & 0.23 \\
\hline $\begin{array}{l}\text { Quality of the music ("This is quality of music to } \\
\text { which the students should be exposed") }\end{array}$ & 0.23 \\
\hline $\begin{array}{l}\text { Aesthetic appeal or value of the music ("This } \\
\text { music provides an aesthetic experience") }\end{array}$ & 0.22 \\
\hline $\begin{array}{l}\text { Technical considerations within the music (range, } \\
\text { tessitura, fingerings, etc.) }\end{array}$ & 0.11 \\
\hline $\begin{array}{l}\text { Historical elements of the music (musical period, } \\
\text { historical period, style) }\end{array}$ & 0.11 \\
\hline
\end{tabular}

Table 4 above reveals that "appeal of the music to colleagues" was reported as being the most influential factor in selecting repertoire. Other leading factors having significant impact upon repertoire selection included "appeal of the music to yourself", "students' appeal to music", "the audience appeal to the music, "rhythmic considerations within the music", and "the potential of the music as heard by school administrators". The least influential factors affecting repertoire selection practices included technical considerations, the aesthetic appeal or value of the music, the music is of high craftsmanship, quality of the music, historical elements of the music, the size of the ensemble, the ability and limitations of the ensemble, melodic considerations, musical elements that can be taught, the cost of the published score and parts, needs of the music library in the director's school, the likelihood of using the music 
more than once, and whether or not the music was newly published.

\section{Discussion}

School band instruction in Ghana, as revealed by the data, seems like a profession reserved solely for males. Reasons for the popularity of wind instruction with the males is difficult to discern from the current data. However, this situation seems to reflect what is happening in other parts of the world with regards to professional musical practices. Men are said to be dominating when it comes to the music profession as a whole. Harrison [30] and Green [31] labelled the active areas of music-making: composing, improvising, and conducting, as traditionally male. Women are left to the more 'passive' areas of accompanying and teaching. Even participating in the so-called 'passive' areas seem not to be the case with the instrumental music teaching profession in Ghana, since not even a single female band instructor was recorded in the instrumental music teaching field.

There is enough evidence in the available literature to support the fact that music as a profession has historically not been open to women instrumentalists [32]. Linda Dahl wrote, "Clearly, the qualities needed to get ahead in the instrumental music world were held to be 'masculine' prerogatives: aggressive self-confidence on the bandstand, displaying one's 'chops' or sheer blowing power; a single-minded attention to career moves, including frequent absences from home and family" [33]. Tucker [34] sums up the gender discussion by attributing the lack of women instrumentalists to three factors: (a) women do not play instruments common to the brass family, (b) gender stereotypes in which women were "perceived as feminine sex spectacles" (p. 979), and (c) limiting women to performance areas more accepting of women, such as novelty or family acts.

In the light of the above, it can be speculated that the instrumentation commonly found with school marching bands (trumpet, trombone, euphonium, and percussion section) includes instruments generally associated with males thus might be a possible explanation for the absence of women band instructors.

All the directors reported they have never seen or consulted any kind of list as an aid in repertoire selection. They have no resources in terms of books to consult when choosing repertoire for their bands. The following statement by one of the instructors illustrated this point when asked about the resources available:

Our schools do not take what we are doing seriously, we are only respected when special school events like anniversaries and speech-and-prize given days are approaching. I do not get the needed support in terms of books... In fact, there is not even a single book on music in our library... It is also very difficult to come by instrumental pieces that are composed specifically for primary school bands in Ghana. Sometimes I turn to the internet (e.g., Google, ApRo Music, YouTube) but most of the sites will require you to pay money before you get access to the full score. I am alone in all this and I do everything all by myself (Personal interview).

Responses given by instructors on the sources of repertoire were numerous. All instructors indicated that most decisions regarded selection of repertoire were taken on their own; meaning there is no organized body or association responsible for such decisions (Interview data). They also indicated that their other colleagues were almost always the first source consulted prior to selecting music. Other leading sources of repertoire selection from the questionnaire included music you performed in other groups, music you performed in high school, music performed in college. Each director indicated that their personal repertoire knowledge was influential in the selection process. It became apparent based on data from the follow-up interviews that each instructor had a personal library of repertoire that they have compiled over the years. A glance through their individual repertoire collections confirmed that virtually all of the works cited by the most experienced instructor among them appeared on the basic repertoire lists of the others. This finding corroborates Dordzro's [28] finding when he revealed that "band directors in Ghana tend to look towards the past when seeking guidance on rehearsal strategies despite the vast literature available on proposed alternatives in philosophy and practice which can be found among the scholarly literature on band" (p. 1).

It was clear from the responses that participants mostly rely on their colleagues and previous band experiences, such as school, community and church bands when making decisions about repertoire to use in their band rehearsals. This is evident in their responses with regards to the various factors that they opined affected their selections such as: "appeal of the music to colleagues", "the potential of the music as heard by school administrators", "the audience appeal of the music", "the student appeal of the music", and "appeal of the music to yourself". Some of the participants spoke highly of their band experiences and former music teachers, viewing them as role models. The following quotation from one of the band instructors attests to that:

...I usually based what I know about repertoire selection on what I experienced in my basic school and church band experiences, where we played many traditional folk tunes, hymns, patriotic songs and marshal music for the brigade and school cadet to march in formation. I still go with those selections because I think it appeals to the students, parents, and most importantly my employers. We are doing just fine, and everybody is happy, I guess (personal interview).

The participants' references to their school, community, and church bands supports the assertion that teachers develop strong beliefs about teaching and learning long before entering the post-secondary classroom [35], [36]. Lortie suggested that these beliefs are formed as a result of the "apprenticeship of observation" (p. 61), whereas Woodford noted, "primary socialization" (p. 676) plays a major role in students' ideas surrounding effective teaching strategies. It is important to honour and recognize these experiences and help teachers think critically about what informs their worldview surrounding teaching and learning, and how any biases may impact the decisions they make. Other factors directors reported to be least influential concerning repertoire selection decisions were the "level of quality of the music", "technical considerations of the music" and "the abilities and limitations of the ensemble performing the music.

It is quite surprising that all the instructors included in this study indicated a desire to teach and perform works that are 
appealing to other people and their individual tastes and biases, but not repertoire selections that are based on technical and pedagogical considerations such as the "quality of the music", "instrumental performance skills that can be taught through the music (phrasing, balance, tone quality etc.)", "historical elements of the music (musical period, historical period, style)", and "social elements of the music (multicultural, social influences of the time, relation of history to society)". These findings from the current research contrast the general views and recommendations in the available literature on repertoire selection for school ensembles.

One of such divergent view is held by Hopkins [25]. According to Hopkins, when choosing repertoire for an ensemble to learn, we should select a piece because we believe it will help our students learn "specific technical skills such as tone quality, articulation, intonation, phrasing and dynamics, or rhythmic precision". We may also programme a piece of music to "expand students' musical understanding of a composer, historical period, musical genre, style, or world culture". More so, we should select repertoire that provides opportunities for structured or free "improvisation or challenges students to expand their thinking about the very nature of music" (p. 69). Many directors strive to programme a diverse selection of works that represents a balance of historical periods, differing tempos, and eclectic styles.

In addition to the above, teachers must have a clear understanding of the educational outcomes they wish to achieve; otherwise, the use of the repertoire may quickly become meaningless. There is, therefore, a good cause for music educators, especially in Ghana, to be concerned about some of the current practices associated with school instrumental music pedagogy. Because the exclusive selection of repertoire based on students/audience appeal may actually hinder the development of musical sensitivity since it does not encourage teachers and learners to focus on the pedagogical elements of the piece. It is therefore critical to note that the central aim of learning music through performance is to create different forms of learning and teaching with the help of an ensemble [37], [38]. The notion expressed in the latter statement has been heavily influenced by constructivist theories of learning. When a learner performs with an instrumental group, the group is seen as a cognitive tool which engages the learner in musical knowledge construction, rather than knowledge reproduction. Cognitive tools help bring about higher-order thinking skills in the learner such as problem-solving, creativity and critical thinking. Moreover, they assist the learner in representing and expressing their knowledge.

Repertoire enumerated by the instructors as a core repertoire for basic school level wind band covered a wide variety of genres, types, and styles. A sizable number of compositions were based on Ghanaian "indigenous folk tunes or melodies", "patriotic tunes", "hymns", "highlife tunes" and "marches" (Interview data). Transcriptions and arrangements of works originally composed for choral groups were mostly included and reflected music from the 1950s through to the present day. Administrative factors such as the cost of the music, needs of the music library, and the likelihood of future study of the music were not important considerations in the repertoire selection process.

Juxtaposing the above findings as against the available literature suggests that most instructors are generally not 'properly' prepared to select repertoire for their school bands. All instructors postulated that undergraduate and college music courses devote little if any, time to the topic of repertoire for the young band (Interview data). While studies in 'applied music', and 'advanced compositional skills' for ensembles such as choral and instrumental groups might be covered in undergraduate or graduate courses, the area of school band instruction; including literature for school bands, remains largely unexplored. This observation finds credence in the available literature that challenges associated with making connections between undergraduate coursework and P-12 teaching experiences are prevalent in music and other teacher education programmes alike [26], [39], [40]. Zeichner [41] stated that the lack of connection between the campus and school-based components is "one of the central problems that has plagued college and university based preservice teacher education for many years" (p. 89), and advocated for a broader epistemology of teacher education... where different sources of knowledge can be used to inform teacher learning" (p. 95). Zeichner reminds us that ultimately, the goal of teacher education is to prepare and mentor preservice teachers, so they are successful in their pursuits to enact the complex task of teaching.

\section{CONCLUSION}

The following conclusions were drawn based on the above findings: The biographical data collected revealed that instrumental music instruction in Ghana is a male-dominated field with not even a single female instructor identified. The process of selecting repertoire for basic school marching bands appears to be reasonably similar among instructors with "other colleagues", and "repertoire performed in college/high school/basic school bands" the most regular source of repertoire. The most influential factors that school band instructors opined affected their selections were: "the potential of the music as heard by school administrators", "the audience appeal of the music", "the student appeal of the music", "appeal of the music to colleagues", and "appeal of the music to yourself".

Repertoire selections among the instructors included in this study are not based on technical and pedagogical considerations such as the "quality of the music", "instrumental performance skills that can be taught through the music", "historical elements of the music and "social elements of the music". But rather the instructors desire to teach and perform works that are appealing to other people and their individual tastes and biases. Instruction is geared not to what the students will derive from the performance, but rather to what the performance will do for the organization and its director, with only side benefits for learners. All instructors indicated that most decisions regarded selection of repertoire were taken on their own; meaning there is no organized body or association responsible for regulating the quality and the developmental level appropriateness of such pieces. 


\section{RECOMMENDATIONS}

Based on the data presented above, it is recommended that schools, colleges, churches, and community bands include positive instrument modelling by both genders into their activities to help break the gender lines and also encourage children to view these instruments as gender-neutral. Also, school administrators should endeavour to make non-musical aspects such as cost, age of the music, and library needs, not be a compelling factor in selecting repertoire of quality and relevance to the school band.

More so, it is recommended that undergraduate and graduate music education courses devote more time to the appreciation and understanding of music for the young band. All known sources of repertoire should be made available to beginning band instructors. Most importantly, music educators in Ghana should publish a repertoire list that will serve as resource for school band instructors.

Lastly, it is suggested that the issue of quality in music be more thoroughly explored in under graduate music education courses. Instruction in universities and colleges should focus on how to determine quality in music, possibly including score study and listening to recordings. Student-teachers should also be exposed to the available literature; including varied selections appropriate to the level of musical maturity of learners, and encouraged to compile a personal reference listing of high-quality band literature, especially including music for the young band.

\section{Suggestion for Future ReSEARCH}

The data presented here must be viewed as an exploratory study of processes band instructors in the Accra metropolis use in the selection of repertoire for their bands. The replication of the current research on bands from other educational districts and regions in Ghana will not be out of place. It is suggested that research of a similar nature be conducted on an even larger scale, locally and perhaps, internationally. There is the need for continued examination of how music teacher educators across the country address the development of repertoire knowledge with their undergraduate and postgraduate students, and an examination of the role fieldwork and student teaching placements play in the music teachers' understanding of how repertoire is used in school bands. Furthermore, determining if repertoire selection and concert programming are fostered in music teacher training curriculum in Ghana, such as undergraduate conducting, is a question that remains unanswered. Lastly, a more complete examination of the repertoire selection processes of experienced and successful band directors could broaden the baseline of descriptive data for instrumental ensemble rehearsals.

\section{REFERENCES}

[1] Volk, T. (2007). Charts and other paraphernalia. Journal of Research in Music Education, 55(4), 302-312.

[2] Forbes, G. (2001). The repertoire selection practices of high school choral directors. Journal of Research in Music Education, 49(2), 102121.

[3] Hayward, C. M. (2004). A course in band literature based on a standard repertoire developed from the opinions of selected collegiate and secondary school band directors (Doctoral dissertation), Ohio State University, USA.

[4] Reynolds, H. R. (2000). Repertoire is the curriculum. Music Educators Journal, 87(1), 31-33.

[5] Weller, T. (2014). Choosing repertoire for middle school band: what important criteria should factor into the selection of your band literature? Teaching Music, 21(4), 26-29.

[6] Apfelstadt, H. (2000). First things first. Music Educators Journal, 87(1). 19-22.

[7] Hoffer, C. R. (2001). Teaching music in the secondary schools (5th ed). Belmont, CA: Wadsworth.

[8] Persellin, D. (2000). The importance of high quality literature. Music Educators Journal, 87(11), 17-18.

[9] Berenson, G. (2008). In unison: A new school year - new repertoire challenges! American Music Teacher, 58(1), 4-5.

[10] Music Educators National Conference. (1994). National standards for arts education. Reston, VA: Music Educators National Conference.

[11] Chen, Y. (2018). An Investigation of Middle School Music Teachers Rationale and Procedure Relating to Instrumental (Band) Repertoire Selection in Southern Ontario: A Case Study (Masters Theses), University of Windsor, Ontario-Canada.

[12] Miller, J. L. (2013). An evaluation of quality in compositions for school band (Grades III and IV): A regional study (Doctoral dissertation), Florida State University, USA.

[13] O'Reilly, J., \& Williams, M. (1998). Standards for judging young band music. The Instrumentalist, 52(12), 12-15.

[14] Gage, S. L. (2000). The importance of repertoire selection for the band director. National Band Association Journal. 41(2), 11-14.

[15] Mayhall, B. (1994). The quest for high quality repertoire. Choral Journal. 35(2), 9-15.

[16] Gregory, M. D. (1986). A descriptive analysis of factors which contribute to job dissatisfaction among secondary school band directors. Dissertation Abstracts International, 47(1), 23-94.

[17] Labuta, J. (1997). Teaching musicianship in the high school band. Fort Lauderdale, FL: Meredith Music Publications.

[18] Coutts, L. (2018). Selecting motivating repertoire for adult piano students: A transformative pedagogical approach. British Journal of Music Education, 35(3), 285-299.

[19] Knight, J. (2001). A gathering of composers for middle school band. The Instrumentalist, 55(12), 14-20.

[20] Leonhard, C., \& House, R. W. (1972). Foundations and principles of music education. New York: McGraw-Hill.

[21] Roseboom, J. D. (2006). Criteria for curricular literature selection among Florida band directors (Doctoral dissertation), Florida State University, USA.

[22] Reimer, B. (1989). A philosophy of music education ( $2^{\text {nd }}$ ed.). Englewood Cliffs, NJ: Prentice-Hall.

[23] Budiansky \& Foley, 2005

[24] Geraldi, K. M. (2008). Planned programming pays dividends. Music Educators Journal, 95(2), 75-79.

[25] Hopkins, M. (2013). Programming in the zone: Repertoire selection for the large ensemble. Music Educators Journal, 23(7), 69-74.

[26] Forrester, S. H. (2017). Repertoire selection for concert band: Preservice music teachers' perceptions and development of knowledge. Research Perspectives in Music Education, 19(1), 14-31.

[27] Baxter, P., \& Jack, S. (2008). Qualitative case study methodology: Study design and implementation for novice researchers. The Qualitative Report, 13(4), 544-559.

[28] Dordzro, J. D. (2017). Impact of Ghanaian Basic School Band Directors' rehearsal strategies on Students' performance (Doctoral Dissertation), University of Cape Coast, Cape Coast, Ghana.

[29] Dordzro, J.-D. (2019). An exploration of Ghanaian basic school marching band pupils' instrument choices. Journal of African Arts \& Culture, 3(3), $25-50$.

[30] Harrison, S. (2010). Boys on the Outer: Themes in Male Engagement with Music. Thymos: Journal of Boyhood Studies, 4(1), 39-53.

[31] Green, L. (1997). Music, gender, education. Cambridge, England: Cambridge University Press.

[32] Jordan, M. (2006). 10X the talent $=1 / 3$ of the credit: How female musicians are treated differently in music (Masters Theses), University of Central Florida, Orlando- Florida.

[33] Dahl, L. (1984). Stormy Weather: The music and lives of a century of jazz women. New York: Pantheon Books.

[34] Tucker, S. (2002). Women. In B. D. Kernfeld (Ed.), The new Grove dictionary of jazz, Vol. 3 (2nd Ed), (pp. 978-984). New York: Grove's Dictionaries.

[35] Lortie, D. (1975). Schoolteacher: A sociological study. Chicago: University of Chicago Press. 
[36] Woodford, P. G. (2002). The social construction of music teacher identity in undergraduate music education majors. In R. Colwell \& C. Richardson (Eds.), The new handbook of research on music teaching and learning (pp. 675-694). New York: Oxford University Press.

[37] Sandholtz, J., Ringstaff, C., \& Dwyer, D. (1997). Teaching with technology: Creating student-centered classrooms. New York: Teachers College Press.

[38] Maddux, C. D., Johnson, D. L., \& Willis, J. (2001). Educational computing: Learning with tomorrow's technologies (3rd ed.). Boston: Allyn and Bacon.

[39] Ballantyne, J. (2006). Reconceptualising preservice teacher education courses for music teachers: The importance of pedagogical content knowledge and skills and professional knowledge and skills. Research Studies in Music Education, 26(37), 37-50.

[40] Haston, W., \& Leon-Guerrero, A. L. (2008). Sources of pedagogical content knowledge. Journal of Music Teacher Education, 17(2), 4859.

[41] Zeichner, K. (2010). Rethinking the connections between campus courses and field experiences in college- and university-based teacher education. Journal of Teacher Education, 61(2), 88-99. 